\title{
KEBIJAKAN SEKTOR INDUSTRI PERTAMBANGAN INDONESIA DALAM REVOLUSI INDUSTRI 4.0
}

\author{
Meiliza Fitri $^{1)}$ dan Wahyudi Zahar ${ }^{2)}$ \\ ${ }^{1)}$ KPKNL Jambi, Direktorat Jenderal Kekayaan Negara, Kementerian Keuangan RI \\ ${ }^{2)}$ Program Studi Teknik Pertambangan, Fakultas Sains dan Teknologi, Universitas Jambi
}

\begin{abstract}
ABSTRAK
Pemerintah RI dalam upaya pengimplementasian Revolusi Industri 4.0 di bidang industri telah menetapkan 10 langkah prioritas nasional, yaitu roadmap yang dikenal dengan Making Indonesia 4.0, yang mencakup perbaikan alur aliran barang dan material, desain ulang zona industri, akomodasi standar-standar keberlanjutan, pemberdayaaan UMKM, pembangunan infrastruktur digital nasional, peningkatan minat investasi asing, peningkatan kualitas SDM, pembangunan ekosistem inovasi, pemberian insentif untuk investasi teknologi, dan harmonisasi aturan dan kebijakan. Melalui pemetaan ini, industri tambang menjadi salah satu unit industri yang penting untuk mewujudkan revolusi industri 4.0. Meskipun pada tahun 2018 trend insdutri global mengalami pergeseran dari industri ekstraktif (extractive industry) menjadi industri disruptif (disruptive industry), seperti perusahaan-perusahaan teknologi maupun perusahaan berbasis R\&D (research and development), revolusi industri tidak serta merta dapat tercapai tanpa adanya peran dari sektor industri ekstraktif, misalnya sektor industri pertambangan, seperti pengadaan bahan baku industri, penggiatan energi terbarukan, hingga penyediaan segala fasilitas dan infrastruktur pendukung bergeraknya revolusi industri 4.0 di Indonesia, contohnya pemenuhan kebutuhan listrik. Untuk itu dilakukan penelitian dengan metode deskriptif kualitatif untuk mengkaji arah kebijakan sektor industri pertambangan sebagai sektor utama dalam mendukung perkembangan revolusi industri di Indonesia. Berdasarkan peraturan pemerintah yang dikeluarkan dalam KEN dan RUEN, serta UU Minerba Nomor 4/2009, terdapat hal mendasar yang perlu diperhatikan pemerintah, yakni kebijakan mengenai ketahanan energi nasional. Pemerintah harus mulai memperhitungkan keterdiaan energi dalam kebijakan yang juga menyangkut pembangunan berkelanjutan (sustainable development) sebagai upaya untuk mengendalikan sumber daya maupun cadangan batubara di dalam negeri untuk sumber energi nasional melalui kebijakan pembentukan Wilayah Cadangan Negara (WPN) khususnya batubara. Pembuatan neraca sumber daya alam sebagai langkah awal pembentukan kebijakan berbasis riset diharapkan dapat ditindaklanjuti dengan perhitungan yang matang mengenai ketahanan energi hingga perhitungan ekonomis terkait kerusakan lingkungan, karena meskip hingga pertengahan tahun 2019 PNBP di sektor mineral dan batubara telah mencapai Rp19,16 triliun atau 44,28\% dari target tahun 2019, terdapat kemungkinan bahwa angka penerimaan ini tidak sebanding dengan besaran nilai yang dibutuhkan untuk kompensasi kerusakan lingkungan yang diakibatkan oleh adanya aktifitas pertambangan. Kebijakan pemerintah kedepannya diharapkan tidak hanya berfokus pada kebijakan DMO, besaran royalti, ekspor impor, hilirisasi, konversi maupun konservasi energi, namun perhitungan matang terhadap ketahanan dan ketersediaan energi nasional melalui pembentukan WCN batubara, karena batubara sebagai target bauran energi utama Indonesia merupakan energi fosil tidak dapat diperbaharui yang diperkirakan habis dalam 71 tahun, dan dapat lebih cepat apabila bauran batubara Indonesia sesuai proyeksi mencapai 38\% di tahun 2025 (asumsi business as usual).
\end{abstract}

Kata Kunci: kebijakan, cadangan energi, batubara 


\begin{abstract}
The Government of Indonesia in the attempt to implement the Industrial Revolution 4.0 through its Ministry of Industry has set 10 national priorities, known as Making Indonesia 4.0, which includes improving the flow of goods and materials, redesigning industrial zones, accommodating the sustainability standards, empowering MSMEs, developing the national digital infrastructure, increasing foreign investment interest, improving the quality of human resources, building an innovative ecosystem, providing incentives for technological investment, and harmonizing rules and policies. Through this roadmap, the mining industry became one of the important industrial units to support the realization of industrial revolution 4.0 in Indonesia. Although in 2018 the global industry trend has shifted from an extractive industry to a disruptive industry, such as technology companies and $R \& D$ (research and development) based companies, the industrial revolution cannot necessarily be achieved without the role of extractive industry sectors, for example the mining industry, in supporting the raw materials, facilities and infrastructure, and electricity. For this reason, a qualitative descriptive study was conducted to examine the policy in terms of mining industry. Based on government regulations issued in KEN and RUEN, and Mining and Minerals Law, there are basic things that need to be considered by the government, namely policies on national energy security. The government must begin to take into account the availability of energy in its policies that also in line with the sustainable development as an effort to control domestic coal resources and reserves for national energy sources by establishing a State Reserve Area (WPN) policy especially for coal. Creating a natural resource balance as a first step in setting up a research-based policy is expected to be followed up by a careful calculation of energy security to economic calculations related to environmental damage, because even with the high amount of PNBP in the mineral and coal sectorthere is a possibility that this is not proportional to the amount of value needed to compensate for the environmental damage. Future government policies are expected to focus not only on DMO policies, royalties, export-imports, downstream, conversion and energy conservation, but also careful calculation of national energy security and availability through the formation of coal WCN, because as Indonesia's main energy mix, coal is fossil energy which estimated to be used up in the next 71 years, and can be faster if the percentage of coal in Indonesian energy mix reaches 38\% in 2025 as projected (business as usual).
\end{abstract}

Keywords: policy, energy reserve, coal

\title{
A. PENDAHULUAN
}

Menjawab tantangan global revolusi Industri 4.0, Indonesia perlu memperhitungkan aspek-aspek strategis yang dapat mendukung implementasi revolusi industri tersebut. Melalui Kementerian Perindustrian, Pemerintah Indonesia telah menyusun inisiatif dalam bentuk suatu roadmap sebagai baseline penerapan revolusi industri 4.0 yang dikenal dengan Making Indonesia 4.0. Dokumen peta jalan ini mencakup sepuluh prioritas nasional, yaitu 1) perbaikan alur aliran material dengan memperkuat produksi material sektor hulu; 2) desain ulang zona industri dengan membangun peta jalan zona industri nasional; 3) akomodasi standar-standar keberlanjutan (sustainability) berupa kesempatan daya saing melalui tren sustainability global; 4) pemberdayaan Usaha Mikro, Kecil, dan Menengah (UMKM) termasuk usaha mikro melalui teknologi; 5) pembangunan infrastruktur digital nasional dengan pembangunan jaringan dan platform digital; 6) peningkatan minat investasi asing dengan menargetkan perusahaan manufaktur terkemuka global melalui penawaran yang menarik dan insentif untuk percepatan transfer teknologi; 7) peningkatan kualitas Sumber Daya Manusia (SDM); 8) pembangunan ekosistem inovasi dengan pengembangan sentra Research and Development and Design (R\&D\&D) oleh pemerintah, swasta, publik, maupun universitas; 9) pemberian insentif investasi teknologi dengan memperkenalkan tax exemption atau subsidi untuk adopsi teknologi dan dukungan pendanaan; dan 10) harmonisasi aturan dan kebijakan dengan 
melakukan harmonisasi kebijakan dan peraturan lintas kementerian (Kementerian Perindustrian, 2018).

Terkait dengan cetak biru Making Indonesia 4.0 atau dikenal pula dengan 4IR, salah satu strategi Indonesia adalah menyiapkan lima sektor manufaktur yang akan menjadi percontohan untuk memperkuat fundamental struktur industri Tanah Air, yakni 1) sektor makanan dan minuman; 2) tekstil dan pakaian; 3) otomotif; 4) kimia; dan 5) elektonik. Pemilihan sektor ini setelah melalui evaluasi dampak ekonomi dan kriteria kelayakan implementasi yang mencakup ukuran PDB, perdagangan, potensi dampak terhadap industri lain, besaran investasi, dan kecepatan penetrasi pasar. Pada dasarnya, pengembangan kelima sektor industri yang menjadi fokus dalam implementasi revolusi industri 4.0 di Indonesia ini tidak terlepas dari dukungan sektor energi sebagai sektor penggerak perekonomian yang kemudian memicu naiknya permintaan energi.

Semakin meningkatnya kebutuhan energi ini menyebabkan isu perlunya kebijakan pencadangan energi domestik sebagai bagian dari ketahanan energi nasional menjadi penting. Sumber daya alam sebagai sumber energi sendiri memiliki peranan penting bagi suatu negara, seperti dikutip dalam resolusi Perserikatan Bangsa-Bangsa (PBB) bahwa kedaulatan permanen atas seluruh kekayaan sumber daya di suatu wilayah dimiliki oleh penduduk dan negara itu sendiri, sehingga seluruh pengusahaannya harus dilakukan demi kepentingan pembangunan nasional dan kesejahteraan penduduk negara tersebut (United Nations, 1962).

Ketahanan energi oleh International Energy Agency didefinisikan sebagai ketersediaan sumber energi yang tidak terganggu dengan harga yang terjangkau yang diukur melalui ketersediaan pasokan atau cadangan energi untuk kurun waktu tertentu, umumnya 90 hari kebutuhan impor setara barel minyak. Ketahanan energi mempunyai dimensi jangka panjang dan jangka pendek. Dalam jangka panjang, ketahanan energi terutama terkait dengan investasi pada persediaan energi yang sejalan dengan perkembangan ekonomi dan lingkungan. Sedangkan dalam jangka pendek, ketahanan energi terutama terkait dengan sistem energi yang mampu bereaksi dengan tepat ketika terjadi perubahan mendadak dalam keseimbangan supply-demand energi. Yergin (2006) mengungkapkan bahwa ketahanan energi adalah akses yang dapat diandalkan dan terjangkau untuk pasokan energi, diversifikasi, integrasi ke pasar energi, dan penyediaan informasi, dimana isu ketahanan energi ini mengalami ekskalasi menjadi isu global dimulai ketika Arab Saudi menghentikan ekspor minyak mentahnya ke negara-negara industri pada awal dekade 70-an yang kemudian mengganggu aktifitas perekonomian di negara-negara Eropa Barat dan Amerika Serikat sebagai importir minyak bumi dari Arab Saudi. Kondisi ini membuat negara-negara di dunia mulai berpikir untuk tidak bergantung pada satu sumber dan satu produsen energi, serta perlunya menjaga pasokan energi.

Terdapat empat aspek utama yang dipertimbangkan dalam menyusun indikator ketahanan energi nasional, yaitu 1) availability atau ketersediaan sumber energi baik dari domestik maupun luar negeri; 2) accessibility atau kemampuan untuk mengakses sumber energi, infrastruktur jaringan energi, termasuk tantangan geografis, geologis, dan geopolitik; 3) affordability atau keterjangkauan biaya investasi energi, mulai dari biaya eksplorasi, produksi, dan distribusi, hingga keterjangkauan konsumen terhadap harga energi; dan 4) acceptability atau penggunaan energi yang ramah lingkungan (darat, laut, dan udara), termasuk penerimaan masyarakat (misal: utilisasi pembangkit listrik tenaga nuklir, dsb). Adapula yang menambahkan dua dimensi lain, yakni dimensi efisiensi (efficiency) dan peran pemerintah (government).

Berdasarkan trilemma index yang dikeluarkan oleh The World Energy Council bekerja sama dengan Oliver Wyman, Indonesia berada pada posisi 69 dari total 128 negara pada tahun 2019. Trilemma index sendiri merupakan alat yang digunakan untuk mengukur kemampuan suatu negara dalam menyediakan energi yang berkelanjutan dilihat dari tiga dimensi, yakni ketahanan energi (energy security), ekuitas energi (energy equity) yang mencakup aksesibilitas dan keterjangkauan, serta keberlanjutan lingkungan (environmental sustainability). Penilaian ini secara keseluruhan 
digunakan untuk mengukur performa suatu negara dalam menjalankan kebijakan bauran energinya. Dari segi ketahanan energi, Indonesia berada pada posisi 34, sedangkan untuk ekuitas energi dan lingkungan yang berkelanjutan, Indonesia berada pada posisi 88 dan 85 .

Per tahun 2018, bauran energi Indonesia mencakup minyak bumi, batubara, gas alam, tenaga air, panas bumi, tenaga surya, tenaga angin, biofuel, biogas, dan energi terbarukan lainnya. Tiga energi yang berperan sebagai energi primer dengan persentase paling tinggi, yakni minyak bumi $(38,81 \%)$, batubara $(32,97 \%)$ dan gas alam $(19,67 \%)$ (Handbook of Energy and Economic Statistics of Indonesia, 2018).

Ketergantungan bauran energi Indonesia terhadap minyak bumi, batubara, dan gas alam yang merupakan energi fosil tidak terbarukan menjadi isu dan tantangan tersendiri karena keberadaan sumber energi ini yang terus mengalami deplesi dan tidak dapat diperbaharui dalam kurun waktu yang singkat, sedangkan lokasi sumberdaya migas (minyak dan gas) serta batubara baru yang dapat menopang kebutuhan energi Indonesia secara kontinu belum banyak ditemukan. Hal ini juga menjadi dasar pemikiran seberapa jauh ketersediaan energi Indonesia untuk memenuhi permintaan energi yang terus meningkat serta mendukung beragam sektor yang menjadi target pengembangan bagi pemerintah terutama dalam menghadapi Revolusi Industri 4.0.

Oleh sebab itu, pemerintah Indonesia, berlandaskan Undang-Undang Nomor 30 Tahun 2007 Pasal 1 Angka 25 yang menyatakan bahwa kebijakan energi nasional merupakan kebijakan pengelolaan energi yang berdasarkan prinsip berkeadilan, berkelanjutan, dan berwawasan lingkungan guna terciptanya kemandirian dan ketahanan energi nasional, membuat kebijakan turunan dengan mengadopsi Kebijakan Energi Nasional (KEN) yang dituangkan dalam Peraturan Pemerintah Nomor 79 Tahun 2014 serta mengeluarkan Rancangan Umum Energi Nasional (RUEN) melalui Peraturan Pemerintah Nomor 22 Tahun 2017. Kebijakan KEN dan RUEN menerapkan beberapa fokus perubahan yang signifikan, yakni terwujudnya elastisitas energi di bawah angka satu, penyusunan kebijakan pemenuhan energi domestik dan menerapkan bauran energi baru yang didasarkan oleh kesediaan energi fosil. Target bauran energi di tahun 2025 mencakup: 30\% batubara, 22\% minyak bumi, 23\% energi terbarukan, dan 25\% gas alam, sedangkan di tahun 2050, bauran energi Indonesia terdiri atas 20\% minyak bumi, 24\% gas alam, 25\% batubara, dan 31\% energi terbarukan. Penelitian ini akan mengkaji kondisi Indonesia terkait dengan ketersediaan wilayah cadangan negara (WCN) berdasarkan kebijakan energi yang ada dengan mengambil fokus pada sumber energi batubara sebagai energi primer dengan cadangan yang relatif lebih besar dibandingkan dengan minyak bumi dan gas alam serta merupakan sumber energi pada sektor pertambangan dengan target bauran energi terbesar Indonesia di masa mendatang.

\section{B. METODOLOGI PENELITIAN}

Metode penelitian yang digunakan merupakan metode deskriptif-kualitatif. Data yang dianalisis dalam penelitian ini berasal dari sumber kajian pustaka terkait data-data sumberdaya dan konsumsi energi, serta kebijakan energi di Indonesia, terutama di sektor pertambangan, dalam 10 tahun terakhir, yakni dari tahun 2009 hingga tahun 2018, yang dihimpun dari berbagai literatur, berupa penelitian terdahulu, peraturan perundang-undangan, serta data dari Kementerian/Lembaga pemerintahan terkait. Selanjutnya analisis dilakukan dengan metode analisis trend dan analisis deskriptif terhadap gambaran kebijakan pemerintah. Analisis deskriptif kualitatif digunakan untuk dasar analisis dan identifikasi pentingnya pembentukan wilayah cadangan negara untuk batubara Indonesia terkait kondisi kebijakan yang berlaku (existing policy) dan data ketersediaan sumber energi batubara. 


\section{HASIL DAN PEMBAHASAN}

\section{C.1. Populasi, Ekonomi, dan Energi}

Jumlah populasi penduduk Indonesia di tahun 2019 mencapai 271,23 juta jiwa atau sekitar 3,5\% dari total populasi dunia, Indonesia berada di peringkat keempat negara berpenduduk terbanyak di dunia setelah Tiongkok (1,44 miliar jiwa), India (1,37 miliar jiwa), dan Amerika Serikat (329,5 juta jiwa) (Worldometers, 2019). Dengan bonus demografi yang cukup besar ini, yakni mencapai tiga kali lipat jumlah rata-rata penduduk di negara-negara Asia Tenggara, diperkuat pula oleh pertumbuhan ekonomi yang salah satunya ditunjukkan dengan peningkatan nilai Produk Domestik Bruto/Gross Domestic Product (PDB/GDP), akan meningkatkan jumlah permintaan energi per individu (Masih dan Masih, 1996). Dalam sepuluh tahun terakhir, angka PDB Indonesia terus mengalami kenaikan rata-rata hingga 7,3\% per tahun, meskipun sempat menurun drastis di tahun 2016. Begitu pula dengan konsumsi energi final atau energi akhir, walaupun angka secara grafis menunjukkan nilai yang fluktuatif di tahun 2012 hingga 2016, tren angka konsumsi energi final juga mengalami peningkatan dengan angka rata-rata 4,3\% per tahun. Di tahun 2017 hingga 2018 terjadi lonjakan angka pertumbuhan PDB yang cukup tinggi, yakni sebesar 11,27\% (Gambar 1).

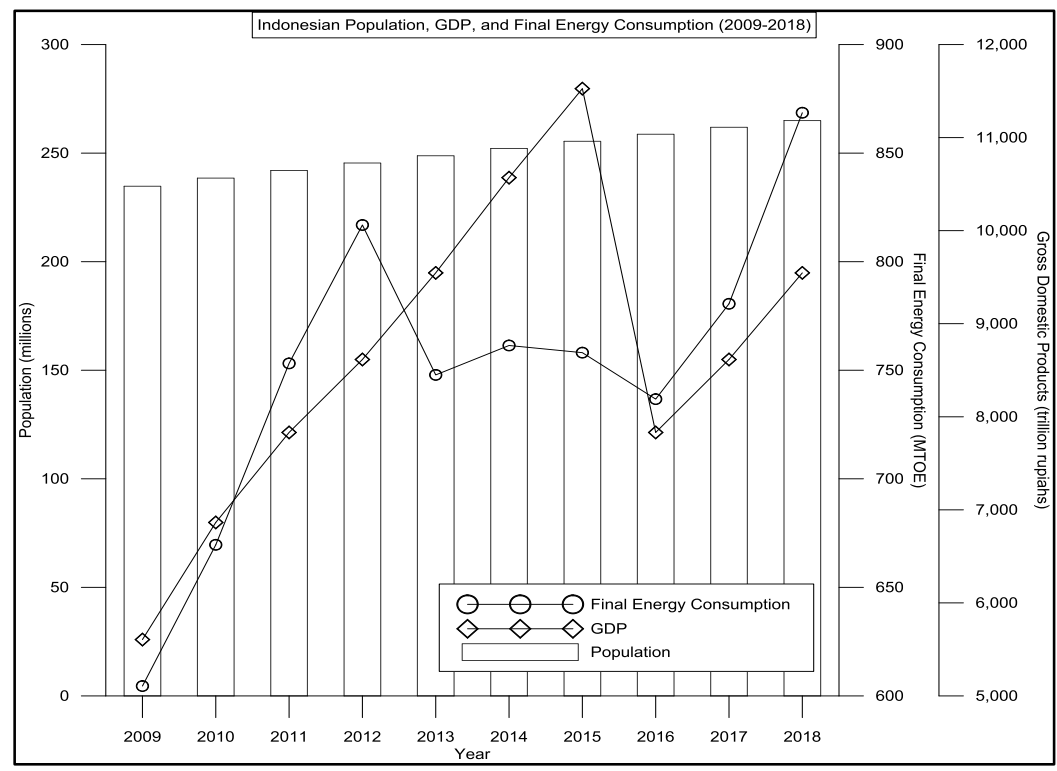

Gambar 1. Grafik Populasi, Pendapatan Domestik Bruto, dan Konsumsi Energi Indonesia tahun 2009-2018 (Sumber Data: Badan Pusat Statistik Indonesia dalam Handbook of Energy and Economic Statistics of Indonesia, 2018)

Energi memiliki peran yang penting sekaligus strategis dalam pertumbuhan ekonomi suatu negara. Selain berfungsi sebagai katalisator pertumbuhan ekonomi, energi juga dijadikan salah satu sumber penerimaan negara. Memasuki era Revolusi Industri 4.0, penggunaan energi di Indonesia tidak lagi dimonopoli oleh sektor industri semata, seperti dapat dilihat pada Tabel 1, mulai tahun 2013, sektor transportasi menggunakan energi dalam jumlah yang lebih tinggi dibandingkan dengan sektor industri. Konsumsi energi pada sektor rumah tangga cenderung stabil, sedangkan sektor komersial dan transportasi terus mengalami peningkatan. Dari tahun 2009 hingga 2018, persentase konsumsi energi pada sektor transportasi naik drastis, yakni sebesar $86,4 \%$ dan terus menunjukkan kecenderungan meningkat, diikuti dengan sektor komersial (45.99\%). Sedangkan penggunaan energi pada sektor lainnya cenderung menurun sekitar $36,35 \%$. 
Tabel 1. Konsumsi energi tahun 2009-2018 (MBOE).

\begin{tabular}{lcccccccccc}
\hline \multicolumn{1}{c}{ Sector } & $\mathbf{2 0 0 9}$ & $\mathbf{2 0 1 0}$ & $\mathbf{2 0 1 1}$ & $\mathbf{2 0 1 2}$ & $\mathbf{2 0 1 3}$ & $\mathbf{2 0 1 4}$ & $\mathbf{2 0 1 5}$ & $\mathbf{2 0 1 6}$ & $\mathbf{2 0 1 7}$ & $\mathbf{2 0 1 8}$ \\
\hline Industrial & 304.79 & 349.04 & 375.21 & 369.70 & 283.56 & 291.22 & 310.59 & 266.94 & 281.46 & 334.47 \\
Households & 143.92 & 144.70 & 145.57 & 147.63 & 149.22 & 152.61 & 148.98 & 149.26 & 149.03 & 151.21 \\
Commercial & 29.56 & 30.94 & 34.13 & 37.14 & 39.24 & 40.25 & 42.45 & 40.28 & 42.30 & 43.15 \\
Transportation & 209.97 & 230.35 & 277.51 & 329.52 & 341.41 & 342.78 & 309.29 & 339.53 & 361.70 & 391.40 \\
Other & 25.29 & 22.34 & 27.22 & 33.71 & 31.11 & 28.69 & 32.84 & 20.39 & 20.84 & 16.10 \\
\hline
\end{tabular}

*Sumber: Kementerian Energi dan Sumber Daya Mineral

\section{C.2. Kebijakan dan Rancangan Energi Nasional Indonesia}

Tingkatan hirarki sumber kebijakan di Indonesia adalah Undang-Undang Dasar 1945, amandemen Undang-Undang, Ketetapan Majelis Permusyawaratan Rakyat (TAP MPR), Ketetapan Dewan Perwakilan Rakyat (DPR), Peraturan Pemerintah, Peraturan Presiden, dan regulasi regional. Peraturan ini umumnya bersifat general dan berperan sebagai pokok-pokok garis besar sehingga membutuhkan peraturan turunan untuk kebijakan detail.

Di sektor energi, Undang-Undang Nomor 30 Tahun 2007 merupakan peraturan utama yang menjadi baseline Peraturan mengenai Kebijakan Energi Nasional (KEN) dan Rencana Umum Energi Nasional (RUEN) dalam mencapai tujuan ketahanan energi dan pencapaian target penggunaan energi baru terbarukan, melalui pencadangan energi nasional untuk mengatasi krisis dan darurat energi, kebijakan harga berdasarkan nilai ekonomi dan besaran subsidi, sekaligus pembentukan Dewan Energi Nasional (DEN) demi ketercapaian target hingga tahun 2025 dan 2050. Kebijakan mengenai pertambangan sendiri diatur melalui Undang-Undang Nomor 4 Tahun 2009 mengenai Kebijakan Pertambangan Mineral dan Batubara yang mencakup kewajiban pemenuhan kebutuhan domestik, yaitu sebesar minimal 24,2\% dari total produksi. Peraturan lain yang terkait dengan kegiatan Pertambangan di Indonesia, misalnya kewajiban bagi produsen batubara Indonesia terkait dengan isu lingkungan yang dijadikan fokus melalui Undang-Undang Nomor 32 Tahun 2009 mengenai lingkungan hidup dan Undang-Undang Nomor 39 Tahun 2004 mengenai pembatasan kegiatan pertambangan di wilayah hutan dan hutan lindung.

Berpedoman pada Peraturan Pemerintah Nomor 22 Tahun 2017 tentang Rencana Umum Energi Nasional (RUEN) dan Peraturan Pemerintah Nomor 79 Tahun 2014 tentang Kebijakan Energi Nasional (KEN), serta Rencana Pembangunan Jangka Menengah Nasional (RPJMN) tahun 20052025, pada dasarnya ketiga peraturan ini menitikberatkan pada ketersediaan energi melalui program diversifikasi sumber energi dengan mengurangi ketergantungan terhadap minyak bumi dan beralih pada batubara dan gas alam, pembangunan, serta kesejahteraan rakyat. Beberapa kebijakan utama terkait pemenuhan penyediaan energi dan pemanfaatan energi final yang tercantum dalam KEN antara lain:

1. Terwujudnya paradigma baru bahwa sumber energi yang semula sebagai komoditi menjadi modal pembangunan;

2. Tercapainya elastisitas energi lebih kecil dari 1 yang diselaraskan dengan target pertumbuhan ekonomi;

3. Tercapainya penurunan intensitas energi final sebesar $1 \%$ per tahun;

4. Memprioritaskan penggunaan energi baru terbarukan serta meminimalkan penggunaan minyak bumi dengan mengoptimalkan pemanfaatan gas bumi dan mengandalkan batubara sebagai pasokan energi nasional;

5. Tercapainya rasio elektrifikasi dan gas rumah tangga;

6. Mengurangi ekspor energi fosil secara bertahap terutama gas dan batu bara, dan menetapkan batas waktu untuk memulai menghentikan ekspor;

7. Tercapainya bauran energi primer yang optimal;

8. Mengurangi subsidi BBM dan listrik secara bertahap sampai dengan kemampuan daya beli 
masyarakat tercapai serta mengalihkan subsidi untuk energi terbarukan; dan

9. Mewajibkan Pemerintah untuk menyediakan Cadangan Penyangga Energi dan cadangan strategis energi, di samping memastikan ketersediaan cadangan operasional oleh badan usaha.

Isu dan permasalahan energi yang menjadi fokus negara Indonesia berdasarkan RUEN diturunkan dalam 10 (sepuluh) fokus berikut:

1. Sumber daya energi masih diperlakukan sebagai komoditas yang menjadi sumber devisa negara, belum sebagai modal pembangunan;

2. Penurunan produksi dan gejolak harga minyak dan gas bumi;

3. Terbatasnya akses dan infrastruktur energi;

4. Ketergantungan terhadap impor Bahan Bakar Minyak dan LPG;

5. Harga Energi Baru Terbarukan (EBT) yang belum kompetitif dan subsidi energi yang belum tepat sasaran;

6. Masih rendahnya pemanfaatan Energi Baru Terbarukan (EBT);

7. Pemanfaatan energi yang belum efisien;

8. Terbatasnya penelitian, pengembangan, dan penguasaan ilmu pengetahuan dan teknologi;

9. Kondisi geopolitik dunia dan isu lingkungan global; dan

10.Belum tersedianya Cadangan Penyangga Energi (CPE).

Berdasarkan kebijakan utama terkait cadangan energi tersebut, KEN membagi cadangan energi nasional menjadi 3 (tiga) jenis yang terdiri dari:

1. Cadangan operasional, yang merupakan cadangan yang wajib disediakan oleh badan usaha dan industri penyedia energi untuk menjamin kontinuitas pasokan energi;

2. Cadangan penyangga energi, yakni cadangan yang disediakan untuk menjamin ketahanan energi nasional sejalan dengan kebijakan efisiensi energi nasional, terutama melalui kebijakan subsidi bahan bakar minyak dan listrik yang tepat sasaran. Cadangan ini digunakan untuk mengatasi kondisi krisis dan darurat energi dan disediakan secara bertahap sesuai kondisi keekonomian dan kemampuan keuangan negara; dan

3. Cadangan strategis, yaitu sumber daya energi untuk masa depan yang sudah diketahui lokasi, jumlah, dan mutunya yang dicadangkan, diatur, dan dialokasikan oleh Pemerintah untuk menjamin ketahanan energi jangka panjang dan dapat diusahakan sesuai waktu yang ditetapkan untuk kepentingan nasional,

\section{C.3. Supply-Demand Energi dan Batubara Indonesia}

Jumlah cadangan batubara Indonesia bukan merupakan yang terbesar secara global, yakni hanya sekitar 3\% dari total cadangan dunia (British Petroleum, 2019), namun batubara memiliki peranan penting sebagai energi primer dalam pemenuhan kebutuhan energi di Indonesia, terutama untuk mendukung kebutuhan listrik nasional serta pemenuhan kebutuhan industri, seperti pabrik semen, besi dan baja. Selain kontribusi batubara secara domestik, ekspor batubara yang cukup tinggi juga merupakan sumber pendapatan bagi negara. Tercatat hingga akhir tahun 2018, jumlah ekspor batubara Indonesia adalah 1,5 miliar setara barel minyak dari total produksi 2,3 miliar setara barel minyak atau sekitar 65\% dari batubara yang diproduksi pada tahun 2018 (Neraca Energi ESDM, 2018). Pendapatan dari batubara dalam 4 tahun terakhir sekitar 31 triliun rupiah atau sekitar $80 \%$ dari total pendapatan yang diperoleh dari sektor non migas. Namun kontribusi pada pendapatan negara terbilang kecil, yakni hanya 1,5 hingga 2\% dari total pendapatan (Aini dalam IESR, 2018).

Produksi batubara meningkat 2,3 kali lipat dalam kurun waktu sepuluh tahun terakhir sedangkan konsumsi energi meningkat hingga 1,1 kalinya. Meskipun produksi batubara melebihi kebutuhan domestik, pemerintah tetap melakukan ekspor batubara karena batubara Indonesia pada umumnya berupa batubara uap (steam coal) atau batubara dengan peringkat rendah (low-rank coal). Produksi batubara dalam negeri ditambah ekspor batubara sebagai supply batubara Indonesia pada dasarnya masih melebihi konsumsi batubara yang dibutuhkan dalam negeri. Tahun 2018, perbandingan antara batubara yang dikonsumsi dengan penyediaan batubara adalah 1:4,8, artinya setiap 4,8 unit persediaan batubara, hanya 1 unit yang dimanfaatkan untuk konsumsi domestik. Angka konsumsi 
yang menunjukkan tren naik hingga 58\% dari tahun teakhir menuntut pemerintah untuk bergerak cepat dalam pembentukan kebijakan untuk menyeimbangkan kebutuhan domestik serta kebijakan ekspor. Ditinjau dari aspek persediaan dan konsumsi energi final batubara, tercatat bahwa dalam sepuluh tahun terakhir terdapat peningkatan dengan kenaikan rata-rata per tahunnya sekitar $4 \%$ (Gambar 2).

Merujuk pada data sumberdaya dan cadangan batubara tahun 2018, jumlah total sumberdaya batu bara Indonesia diperkirakan sekitar 151 miliar ton, dengan cadangan hingga 40 miliar ton, dan angka produksi mencapai 558 juta ton (Kementerian Energi dan Sumber Daya Mineral, 2018). Apabila terhadap angka parameter cadangan dan produksi diasumsikan tidak adanya penemuan sumber daya baru, penambahan cadangan, dan tingkat produksi konstan, serta kebijakan pemerintah berjalan dengan sistem BAU (business as usual), diperkirakan usia batubara Indonesia hanya mampu mencapai 71 tahun.

Berdasarkan perhitungan sederhana ini, potensi batubara sebagai sumber energi primer cadangan masih cukup strategis dibandingkan energi fosil lainnya. Namun, angka produksi beberapa tahun terakhir melebihi target yang ditetapkan dalam Rencanan Pembangunan Jangka Menengah Nasional (RPJMN) Indonesia tahun 2014-2019, yakni produksi sebesar 400 juta ton batubara di tahun 2019. Hal ini disebakan oleh kebijakan pemerintah di awal tahun 2018 yang memberi kesempatan produsen batubara untuk meningkatkankan produksi di atas 500 juta ton dengan tujuan untuk meningkatkan pendapatan dari perdagangan batubara, kompensasi kebijakan DMO (domestic market obligation), serta membantu keseimbangan defisit anggaran dari sektor minyak dan gas.

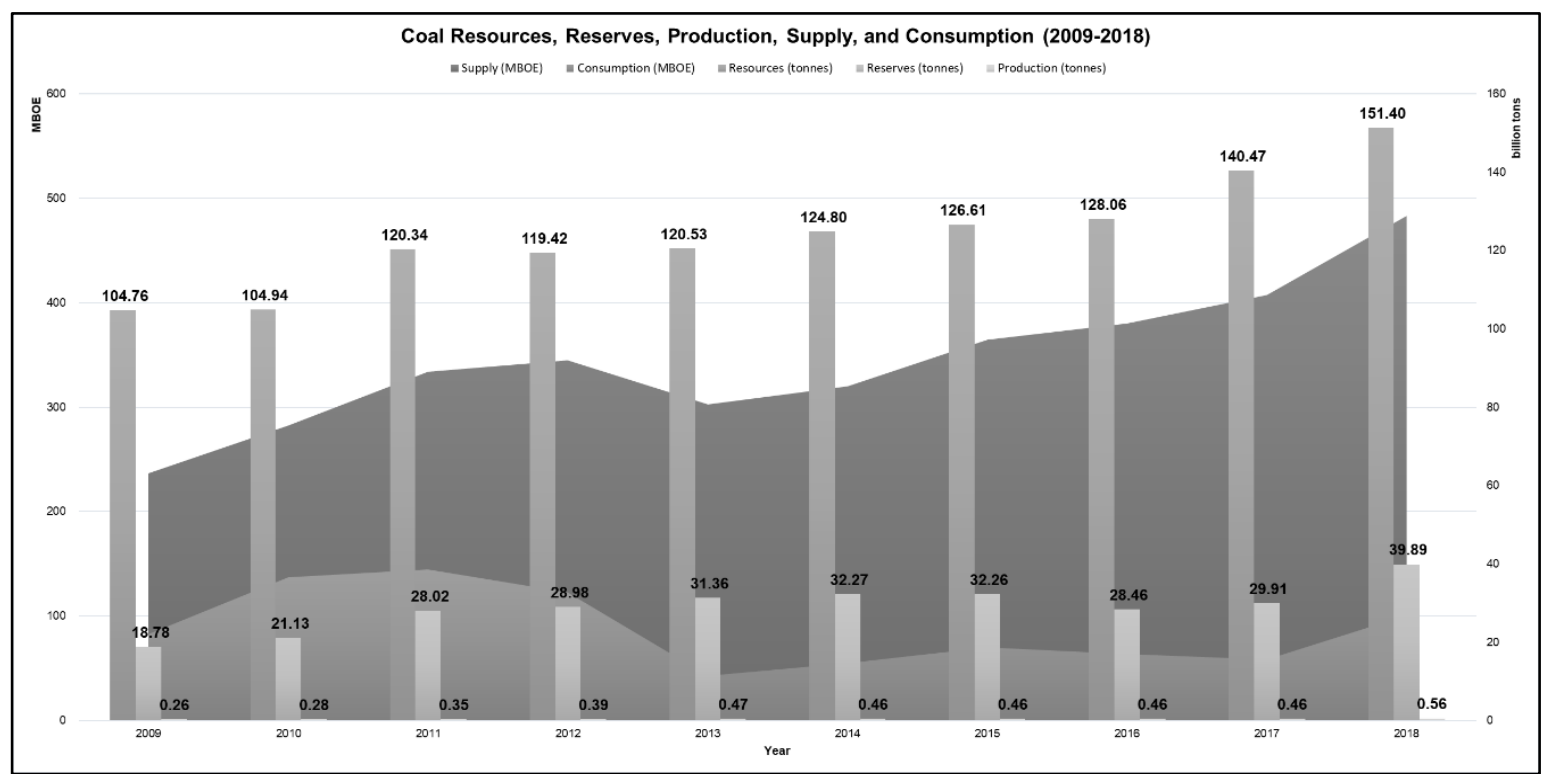

Gambar 2. Jumlah Sumber daya, Cadangan, Produksi, Supply, dan Konsumsi Batubara di Indonesia dari tahun 2009-2018 (Sumber Data: Kementerian Energi dan Sumber Daya Mineral dalam Handbook of Energy and Economic Statistics of Indonesia, 2018)

Ketergantungan pemerintah terhadap pendapatan dari ekspor batubara merupakan kebijakan yang kurang tepat karena ketidakpastian harga batubara secara global serta adanya kebijakan pengurangan penggunaan batubara untuk memenuhi target pengurangan emisi gas karbon dioksida $\left(\mathrm{CO}_{2}\right)$. Untuk mencapai tujuan KEN dan RUEN, produksi batubara ini perlu dikendalikan, melalui pengurangan ekspor secara bertahap dan peningkatan pemanfaatan domestik. Pada awal tahun 2011, Pemerintah mengeluarkan kebijakan pelarangan ekspor batubara dengan nilai kalori dibawah 5400 kalori/gram yang rencananya diberlakukan pada awal tahun 2014 dengan tujuan menjaga cadangan batubara serta memacu produsen batubara untuk meningkatkan kualitas batubaranya sebelum dilakukan ekspor. Namun kebijakan ini dibatalkan di awal tahun 2013 dengan melakukan 
pembatasan produksi batubara per area. Pemerintah kemudian menerapkan kebijakan DMO (domestic market obligation) melalui pemberian insentif ekonomi untuk mendorong pasokan dan penggunaan dalam negeri termasuk coal liquefaction, upgrading brown coal (UBC), dan gasifikasi batubara serta teknologi batubara bersih lainnya yang diatur dalam Peraturan Menteri ESDM Nomor 34 Tahun 2009 tentang Pengutamaan Pemasokan Kebutuhan Mineral dan Batubara untuk Kepentingan Dalam Negeri dan diturunkan melalui Keputusan Menteri ESDM 2805.K/30.MEM/2015. Dalam peraturan ini disebutkan bahwa dalam rangka pengutamaan pemasokan kebutuhan batubara untuk kepentingan dalam negeri, Badan Usaha Pertambangan Batubara wajib menjual batubara yang diproduksinya kepada Pemakai Batubara berdasarkan Persentase Minimal Penjualan Batubara yang ditetapkan oleh Menteri dan dituangkan dalam perjanjian jual beli batubara antara Badan Usaha Pertambangan Batubara dengan Pemakai Batubara..

\section{C.4. Batubara dalam Bauran Energi Indonesia}

Meskipun Pemerintah melakukan diversifikasi sumber energi melalui kebijakan RUEN dan KEN, batubara tetap menjadi primadona pada target bauran energi Indonesia, terutama untuk pemenuhan pasokan pembangkit listrik tenaga uap, dalam rangka meningkatkan persentase elektrifikasi di Indonesia. Bauran energi (energy mix) Indonesia pada tahun 2020, terdiri dari 83,2\% energi fosil yang terdiri dari minyak bumi, gas alam, dan batubara, dan 16,8\% energi baru terbarukan (EBT) dan energi lainnya. Pada tahun 2025, 2030, dan 2040 persentase energi fosil ini terus mengalami penurunan dengan angka persentase bauran maksimal menjadi $83,2 \%, 77 \%$, dan $75,2 \%$, sedangkan untuk EBT dan energi lainnya terus mengalami peningkatan menjadi minimal 22,6\%, 24,8\%, dan 28\%. Sejauh ini, kebijakan pemerintah yang dituangkan dalam KEN dan RUEN baru menetapkan target bauran energi Indonesia hingga tahun 2050, dimana persentase bauran energi fosil maksimal adalah $69 \%$, sedangkan minimal $31 \%$ bauran energinya berasal dari sumber energi EBT dan energi lainnya (Tabel 2 dan Gambar 3).

Tabel 2. Existing Bauran Energi dan Target Bauran Energi Indonesia Sesuai KEN dan RUEN

\begin{tabular}{lrrrrrr}
\hline Jenis Sumber Energi / Tahun & $2018^{1}$ & $2020^{2}$ & $2025^{2}$ & $2030^{2}$ & $2040^{2}$ & $2050^{2}$ \\
\hline Minyak Bumi* & 38.81 & 32.1 & 25 & 22.1 & 20.9 & 20 \\
Gas Alam* & 19.67 & 22.1 & 22 & 23 & 24.1 & 24 \\
Batubara* & 32.97 & 29 & 30 & 30.1 & 27 & 25 \\
Biomassa* & 1.95 & 5.5 & 9.7 & 9.8 & 12.9 & 14.2 \\
Panas Bumi* & 1.78 & 7.9 & 7.1 & 6.5 & 4.9 & 5.8 \\
Air* & 2.74 & 1.7 & 2.6 & 2.5 & 1.8 & 2 \\
Laut* & 0 & 0 & 0 & 0.2 & 0.3 & 0.4 \\
Surya* & 0.02 & 0 & 0 & 0.2 & 1.5 & 1.7 \\
Angin* & 0.03 & 0 & 0 & 0 & 0.1 & 0.1 \\
Energi lainnya* & 2.03 & 1.7 & 3.2 & 5.6 & 6.5 & 6.8 \\
\hline
\end{tabular}

*Sumber Data: ${ }^{1}$ Kementerian Energi dan Sumber Daya Mineral, ${ }^{2}$ Kebijakan Energi Nasional dan Rancangan Umum Energi Nasional (data diolah, dalam persentase) 


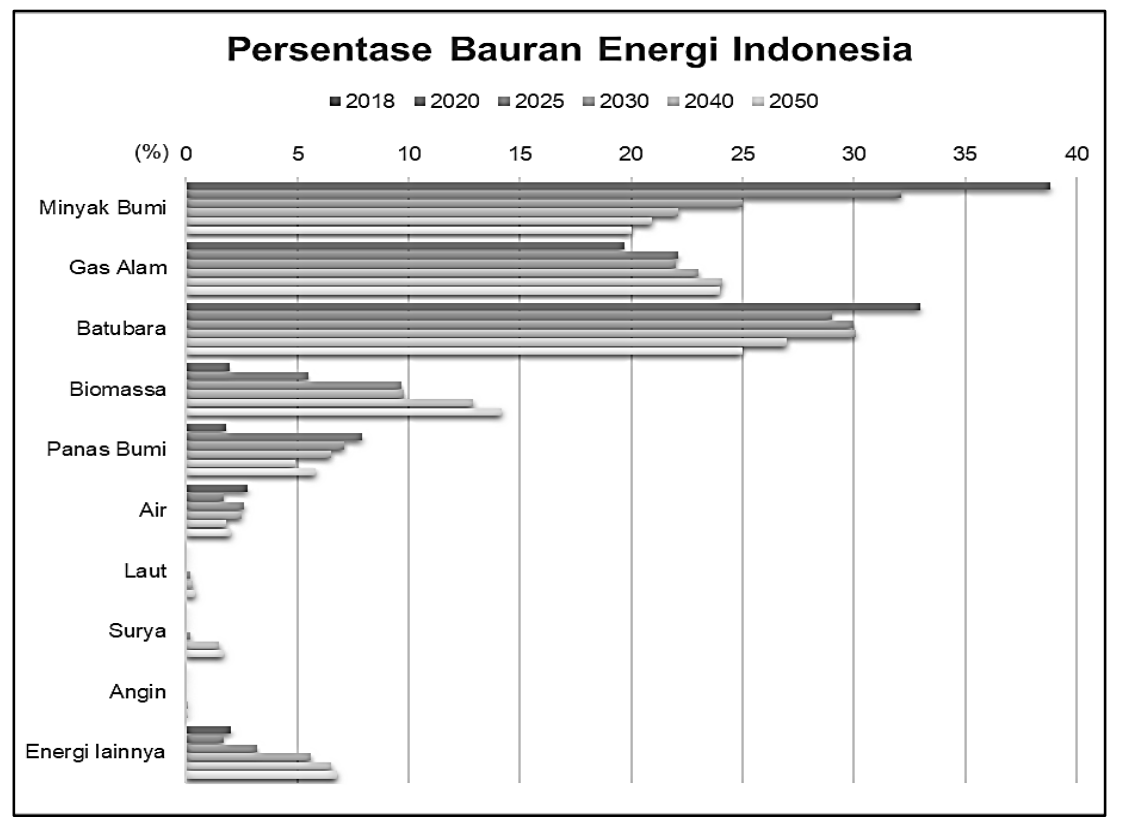

Gambar 3. Persentase Existing dan Target Bauran Energi Indonesia Sesuai KEN dan RUEN

Hingga akhir tahun 2018, bauran energi Indonesia masih berupa 91,45\% energi yang bersumber dari fosil dan baru 8,55\% bersumber dari EBT dan energi lainnya. Minyak bumi masih merupakan bauran energi dengan persentase terbesar dibandingkan dua energi primer lainnya hingga tahun 2020. Namun pada tahun 2025, target persentase bauran tertinggi mulai digantikan oleh batubara yakni sebesar 30\%, dan meski angka persentase bauran batubara tahun 2030 cenderung naik meski tidak signifikan, yaitu sebesar 0,1\%, dan menurun kembali di tahun 2040 ke angka 27\%, hingga 25\% di tahun 2025, batubara tetap merupakan sumber energi andalan Indonesia, setidaknya hingga 31 tahun kedepan.

Berdasarkan target persentase bauran energi ini, Sugeng dan Tiess (2013) memperkirakan terdapat dua skenario bauran energi hingga tahun 2025 yang mungkin terjadi berdasarkan beberapa asumsi dari parameter Market Allocation (Markal) model (Seebregts et al., 2001), yakni skenario konsumsi tinggi (high consumption) atau business as usual (BAU) dan skenario ideal yakni low or efficient consumption sesuai dengan target yang ditentukan. Pengembangan skenario ini didasarkan dengan asumsi parameter kunci yang mencakup pertumbuhan populasi $0,8 \%$ pada tahun 2025; pertumbuhan PDB 6,6 - 8\%; pertumbuhan konsumsi listrik 7\% di tahun 2010 dan 8,4\% in 2025. Parameter ini juga dikalkulasi menyesuaikan pengurangan emisi karbon sebesar 20 hingga $26 \%$ pada tahun 2020.

Menggunakan skenario BAU dengan asumsi tidak ada kebijakan baru hingga tahun 2025, didapatkan total konsumsi energi di tahun 2025 sebesar 450 MTOE, dengan bauran energi 22,2\% minyak bumi, 17,8\% gas alam, 37\% batubara, 19,2\% EBT, dan 4\% energi lainnya. Skenario ini mengimplikasikan masih tingginya konsumsi energi primer, yang menyebabkan percepatan penurunan cadangan sumber energi primer tanpa manajemen yang baik dan melemahkan ketahanan energi nasional. Selain itu, skenario ini juga masih menghasilkan emisi karbon yang cukup tinggi. Skenario ideal merefleksikan efisiensi yang tinggi dan adanya diversifikasi sumber energi, terutama EBT. Dengan asumsi konsumsi energi total 159 MTOE di tahun 2010 dan 380 MTOE pada tahun 2025 , komposisi bauran energi menjadi $23,7 \%$ minyak bumi, $19,7 \%$ gas alam, 30,7\% batubara, 3,2\% energi lainnya, dan $22,7 \%$ EBT. Skenario ini ditetapkan sebagai skenario yang ramah lingkungan dengan tingginya bauran energi EBT, mampu menjaga ketersediaan sumber daya energi, dan rendah emisi sehingga mampu meningkatkan ketahanan energi Indonesia. 


\section{C.5. Wilayah Cadangan Negara Batubara}

Berdasarkan KEN dan RUEN sebagai turunan dari Undang-Undang No. 30 Tahun 2007, salah satu cara untuk membangun katahanan energi adalah dengan membuat cadangan energi nasional yang terdiri dari cadangan operasional, cadangan penyangga energi (CPE), dan cadangan strategis. $\mathrm{CPE}$ didefinisikan sebagai jumlah ketersediaan sumber energi dan energi yang disimpan secara nasional yang diperlukan untuk memenuhi kebutuhan energi nasional pada kurun waktu tertentu, disediakan oleh Pemerintah dan digunakan untuk mengatasi kondisi krisis dan darurat energi yang menyebabkan gangguan suplai energi, sebagai contoh, menurunnya jumlah produksi, peperangan, bencana alam, dan hal-hal lain yang dapat menimbulkan krisis energi. Cadangan ini berfungsi untuk menjaga stabilitas pasokan energi dalam negeri pada saat terjadi gangguan dari dalam maupun luar negeri. Sampai saat ini Pemerintah baru memiliki cadangan operasional dan cadangan strategis. Sebagai perwujudan ketahanan energi nasional, Pemerintah juga sempat merencakan adanya Dana Ketahanan Energi (DKE) dan dibatalkan karena tingginya resistensi masyarakat. DKE berfokus pada diversifikasi sumber energi yang memprioritaskan EBT (energi baru terbarukan) dan pembangunan cadangan minyak strategis (strategis petroleum reserve). Cadangan energi Indonesia dalam bentuk stok batubara nasional belum tersedia, mengingat persentase bauran batubara yang cukup tinggi hingga tahun 2050, dan apabila tidak adanya kebijakan pencadangan batubara dan peraturan maupun kebijakan pemerintah di sektor pertambangan batubara berjalan dengan konsep business as usual, berdasarkan data bauran energi batubara dari tahun ke tahun dalam satu decade terakhir, maka diproyeksikan bauran energi dari batubara dapat mencapai sekitar $38,25 \%$. Angka ini melebihi target bauran energi di tahun 2025 berdasarkan KEN dan RUEN yang menetapkan bauran energi batubara sebesar $30 \%$.

Permintaan dan bauran batubara yang tinggi juga dikarenakan belum tercapainya rasio elektrifikasi di Indonesia secara menyeluruh dari target elektrifikasi pada daerah terpencil Indonesia hingga 90\% di tahun 2020. Batubara dipilih sebagai sumber energi andalan untuk pembangkit tenaga listrik karena harganya yang relatif lebih murah dibandingkan dengan sumber energi lainnya, sehingga biaya yang dibutuhkan untuk memproduksi listrik pun lebih rendah. Terkait dengan isu lingkungan, yang perlu menjadi prioritas bagi pemerintah sebagai konsekuensi pemilihan batubara adalah meningkatkan efisiensi dari pembangkit listrik agar utilisasi sumber daya batubara termanfaatkan dengan baik sekaligus meminimalisir emisi karbon dioksida.

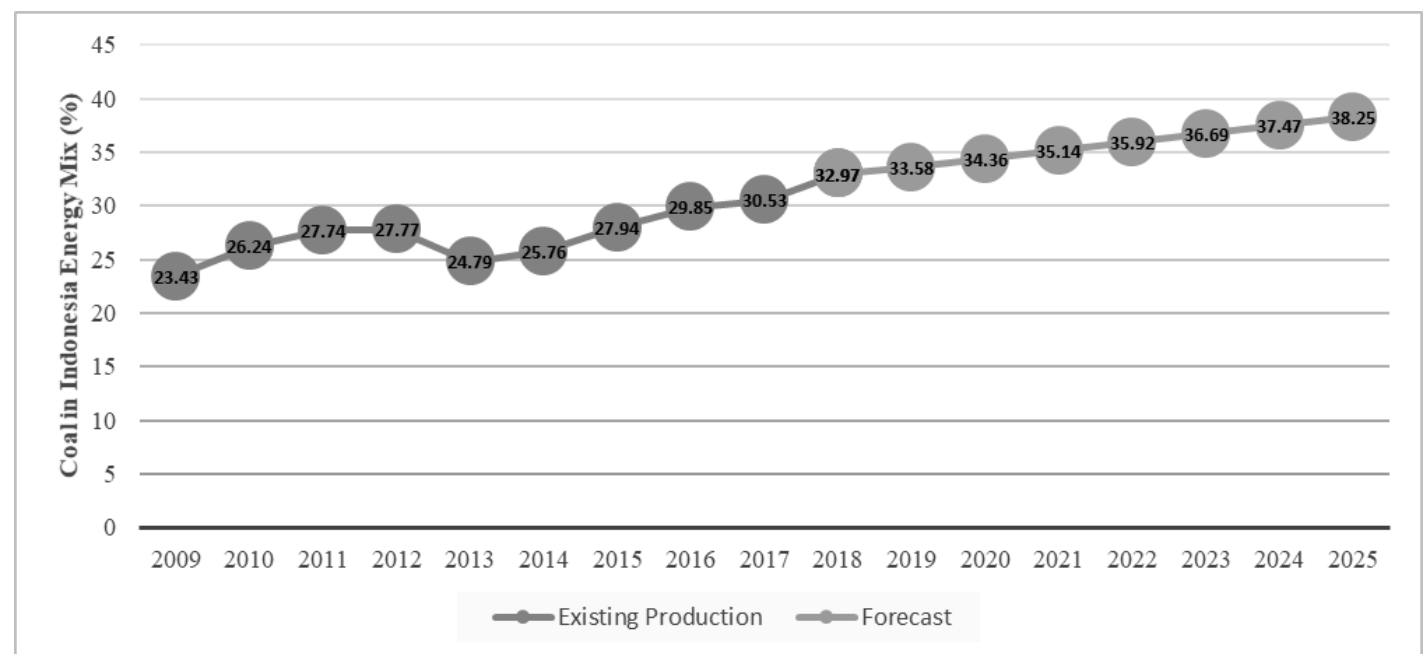

Gambar 4. Prediksi bauran energi batubara Indonesia dengan konsep business as usual (BAU)

Berdasarkan hal-hal di atas, keberadaan wilayah cadangan negara (WCN) Batubara sangat diperlukan dengan pertimbangan sebagai berikut: 1) gangguan supply dan demand dalam tingkat global dapat terjadi dan mengakibatkan krisis energi baik bagi negara pengimpor maupun pengekspor batubara; 2) WCN batubara sangat bermanfaat untuk menjamin ketersediaan energi dan mengendalikan harga batubara dalam negeri ketika terjadi krisis darurat energi; 3) WCN 
batubara memiliki peranan penting dalam menjaga kestabilan ekonomi, sosial dan politik, khususnya bagi negara Indonesia sebagai eksportir besar batubara dunia; dan 4) kebutuhan dan permintaan yang masih tinggi di pasar domestik terutama sektor kelistrikan terhadap ketersediaan batubara. Keberadaan WCN batubara ini juga merupakan amanat Undang-Undang Nomor 30 Tahun 2007 dan bagian dari fokus KEN dan RUEN mengenai cadangan nasional sumber energi yang penyediaannya secara bertahap sesuai dengan kondisi perekonomian dan keuangan negara.

Pendanaan pembentukan wilayah cadangan negara batubara ini dapat menggunakan skema yang sama dengan cadangan minyak, seperti pembangunan area/wilayah penyimpanan (storage) melalui alokasi Penyertaan Modal Negara (PMN) atau Belanja Infrastruktur Kementerian/Lembaga, penggunaan dana APBN melalui dana cadangan dalam belanja lain-lain (BA. 008), dan 3) pembiayaan melalui Daftar Isian Pelaksanaan Anggaran (DIPA) Kementerian ESDM. Sebelum tercapainya cadangan energi nasional melalui pembentukan WCN ini, Pemerintah melalui APBN juga perlu mengalokasikan anggaran secara bertahap sampai pemenuhan cadangan selama 30 hari konsumsi, sesuai ketentuan dari Dewan Energi Nasional atau 90 hari konsumsi berdasarkan International Energy Agency dapat terpenuhi.

\section{KESIMPULAN}

Penelitian ini bertujuan untuk mengkaji kebijakan pemerintah yang ada terkait dengan cadangan energi nasional yang berfokus pada salah satu sumber daya yang berasal dari sektor pertambangan, yakni batubara. Berdasarkan hasil penelitian, ditemukan bahwa peningkatan konsumsi energi di Indonesia, seperti layaknya yang terjadi di berbagai negara lain, disebabkan oleh peningkatan ekonomi yang salah satu indikatornya ditunjukkan dengan nilai PDB dan peningkatan jumlah populasi. Dalam sepuluh tahun terakhir, populasi di Indonesia naik rata-rata $1,4 \%$ per tahun, kenaikan PDB rata-rata 7,3\% per tahun, dan konsumsi energi meningkat 4,3\% per tahun. Oleh sebab itu, ketersediaan dan kebutuhan energi di masa mendatang selayaknya memperhitungkan dua parameter ini.

Fokus utama akibat kenaikan permintaan pemenuhan energi ini adalah posisi pengelolaan energi Indonesia yang masih rendah. Indonesia memili potensi untuk mengimplementasikan kebijakan terkait sektor energinya, baik persediaan energi, maupun produksinya. Pemerintah melalui Kebijakan Energi Nasional (KEN) dan Rancangan Umum Energi Nasional (RUEN) sudah memiliki tujuan yang jelas terkait dengan arah kebijakan energi di Indonesia, yakni perlunya ketersediaan energi untuk pemenuhan kebutuhan nasional, prioritisasi pengembangan energi, penggunaan energi untuk kepentingan domestik/nasional, serta adanya cadangan nasional.

Menyikapi kebutuhan energi nasional yang terus bertambah, sedangkan energi primer yang menjadi tulang punggung penyediaan sumber energi berasal dari energi fosil yang tidak dapat diperbaharui, pemerintah belum membuat kebijakan turunan berupa peraturan teknis, kebijakan konservasi, diversifikasi, infrastruktur, penggunaan teknologi, serta pembiayaan dan insentif terkait dengan penyediaan cadangan energi nasional, khususnya sumber energi yang berasal dari batubara. Produksi batubara naik 2,3 kali lipat dalam jangka waktu sepuluh tahun terakhit dan diperkirakan akan terus mengalami peningkatan sejalan dengan masih tingginya target bauran energi batubara yang mencapai $30 \%$ pada tahun 2025 dan $25 \%$ pada tahun 2050 mendatang, disertai dengan kebutuhan pemenuhan rasio elekstrifikasi nasional.

Usia batubara dengan asumsi business as usual diperkirakan sekitar 71 tahun, namun angka ini dapat berkurang melihat kecenderungan kenaikan bauran energi Indonesia dalam 10 tahun terakhir, yang diproyeksikan mencapai $38 \%$ pada tahun 2025, melebihi target bauran energi sebesar $30 \%$. Berdasarkan hal tersebut, pemerintah dirasa perlu untuk segera menentukan arah kebijakan pencandangan energi untuk sumberdaya batubara melalui penanganan yang intensif dengan pembentukan wilayah cadangan negara $(\mathrm{WCN})$ batubara. Meskipun kebutuhan dalam negeri saat 
ini masih di bawah jumlah total produksi yang dihasilkan oleh tambang batubara, pemerintah haru lebih bijak dalam mengatasi eksploitasi sumberdaya secara berlebihan atas cadangan tambang batubara dalam rangka meningkatkan opportunity cost yang mencerminkan selisih biaya antara energi untuk menggantikan batubara di masa yang akan datang terhadap penggunaan batubara di masa yang akan datang sebagai upaya untuk mengurangi ketergantungan terhadap sumber daya minyak.

Dalam rangka pembentukan WCN batubara ini, pemerintah dapat: 1) memastikan kebutuhan ketersediaan energi; 2) mengoptimalkan produksi dan eksploitasi sumber daya batubara melalui pengembangan berbasis manajemen sumber daya karena penurunan produksi batubara sebagai pemenuhan target bauran energi ideal di Indonesia sekaligus untuk menjaga cadangan batubara domestik dapat memicu fluktuasi harga; 3) mengkaji kebijakan subsidi pada sektor energi; dan 4) mengembangkan kebijakan konversi, konservasi, maupun diversifikasi energi sebagai bagian dari upaya untuk menjaga cadangan sumber energi. KEN dan RUEN menetapkan bahwa energi merupakan modal pembangunan nasional, bukan hanya penghasil devisa, namun peraturan perundang-undangan yang ada belum sepenuhnya mendukung kebijakan tersebut. Pembangunan WCN batubara juga membutuhkan dukungan kebijakan turunan berupa aturan, strategi, kerangka kerja yang lebih detail seperti target fasa pembangunan cadangan energi nasional dan peta jalan cadangan energi batubara, serta penyediaan pembiayaan infrastruktur.

\section{DAFTAR PUSTAKA}

British Petroleum. (2019). BP Statistical Review of World Energy 2019, 68th edition, 42.

Data jumlah penduduk diperoleh dari data Worldometers tanggal 28 April 2019, data diperoleh melalui situs internet https://www.worldometers.info/world-population/, diakses pada tanggal 15 September 2019.

Data trilemma index diperoleh dari data World Energy Council tahun 2019, data diperoleh melalui situs internet https://trilemma.worldenergy.org/, diakses pada tanggal 6 September 2019.

IEA. (2013). Southeast Asia Energy Outlook. International Energy Agency. Energy security. definisi diperoleh melalui situs internet http://www.iea.org/topics/energysecurity/, diakses pada tanggal 14 Agustus 2019.

Institute for Essential Services Reform (IESR). (2018). Indonesia's Coal Dynamics: Toward A Just Energy Transition, First Edition, March 2019, 7.

Kementerian Energi dan Sumber Daya Mineral. (2018): Handbook of Energy \& Economic Statistics of Indonesia, 11-63.

Kementerian Perindustrian Republik Indonesia. (2018): Making Indonesia 4.0, 4-8.

Masih, A.M.M. dan Masih,R.. (1996): Energy consumption, real income and temporal causality: results from a multi-country study based on cointegration and error-correction modelling techniques, Energy Economics, 18, 165-183.

Mujiyanto, S. dan Tiess, S. (2013). Secure energy supply in 2025: Indonesia's need for an energy policy strategy, Energy Policy, 61, 31-41.

Seebregts, A.J., Goldstein, G.A., Smekens, K. (2001). Energy/environmental modeling with the MARKAL family of models, Operations Research Proceedings.

United Nations. (1962). United Nations Resolution No. 1803 (XVII), 1194th Plenary meeting, 14 Desember 1962.

Yergin, D. (2006). Ensuring energy security, Foreign Affairs, 69-82. 
PROSIDING TPT XXVIII PERHAPI 2019 